\title{
Arsenic in Latin America
}

\author{
Marta I. Litter ${ }^{1,2^{*}}$, María A. Armienta ${ }^{3}$, Ruth E. Villanueva-Estrada ${ }^{4}$, \\ Edda C. Villaamil Lepori ${ }^{5}$ and Valentina Olmos ${ }^{5}$ \\ ${ }^{1}$ Gerencia Química, Comisión Nacional de Energía Atómica-CONICET, Argentina \\ ${ }^{2}$ Instituto de Investigación e Ingeniería Ambiental, Universidad Nacional de General San Martín, Argentina \\ ${ }^{3}$ Universidad Nacional Autónoma de México, Instituto de Geofísica, Ciudad de México, México \\ ${ }^{4}$ Universidad Nacional Autónoma de México, Instituto de Geofísica, Unidad Michoacán, México \\ ${ }^{5}$ Cátedra de Toxicología y Química, Facultad de Farmacia y Bioquímica, Universidad de Buenos Aires, Argentina \\ *Corresponding author. E-mail: marta.litter@gmail.com
}

\begin{abstract}
An overview of arsenic (As) presence in waters in Latin America (LA) is presented. Aspects on As occurrence, effects of As on human health, regulations regarding the maximum allowable concentration of As in drinking water, analytical techniques for As determination, and conventional/emerging technologies for As removal developed in LA are mentioned. Arsenic presence has been identified in many

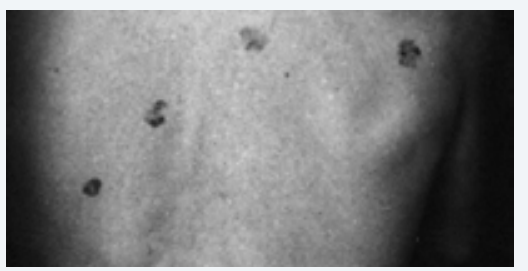
LA countries in a range of concentrations, originated from various sources; however, its origin is mainly natural. Main analytical techniques available in LA laboratories are described. Pathologies derived from the chronic consumption of As, the metabolism of As in the human body and the effects of the different As chemical forms are detailed. A list of conventional and emerging technologies for As removal in LA waters for human consumption, for large, medium and small populations, rural and periurban, is reported. Conclusions and recommendations to face the problem are included.
\end{abstract}

\section{Keywords:}

Arsenic, occurrence, analytical methodologies, health effects, regulations, removal technologies

\section{Introduction}

Arsenic (As) is a metalloid abundantly present in the Earth's crust. Exposure in humans occurs through the consumption of contaminated water and food [1]. Pollution comes mainly from natural sources, i.e., from the release of As to soil and aquifers due to volcanic phenomena and disintegration of rocks. A few anthropic activities such as mining, industrial processes, smelting of metals, production of pesticides and wood preservatives [1] are sources of contamination. Although natural mineralization and microbial activities increase the mobilization of As in the environment, human activities exacerbate As contamination in soil and in water supplies [2]. Chronic exposure to As via drinking water has received more and more attention for its high prevalence in many parts of the world, and for the growing body of evidence of its impact on health [3]. Contamination of water by As is a worldwide problem with high impact in the poorest regions [4], with more than 226 million people exposed [5,6]. The most affected populations are those in low income countries. The higher concentrations and, consequently, the most significant health problems are localized in Argentina, Bangladesh, Nepal, Chile, China, Hungary, India, Mexico, Romania, Taiwan, Vietnam and the USA [7]. In Latin America (LA), the problem affects at least 14 countries (Argentina, Bolivia, Brazil, Chile, Colombia, 
Cuba, Ecuador, El Salvador, Guatemala, Honduras, Mexico, Nicaragua, Peru and Uruguay), and the number of exposed people could be estimated in around 14 million. The most critical areas are in Argentina, Chile and México $[8-9,10,11,12]$.

\section{Distribution of arsenic in Latin America}

Arsenic presence has been identified in many LA countries in a wide range of concentrations from various sources, mainly natural. Arsenate $(\mathrm{As}(\mathrm{V}))$ is the most abundant chemical form. A summary of As occurrence in each country is given below. Figure 1 shows the countries where natural As in water has been detected.

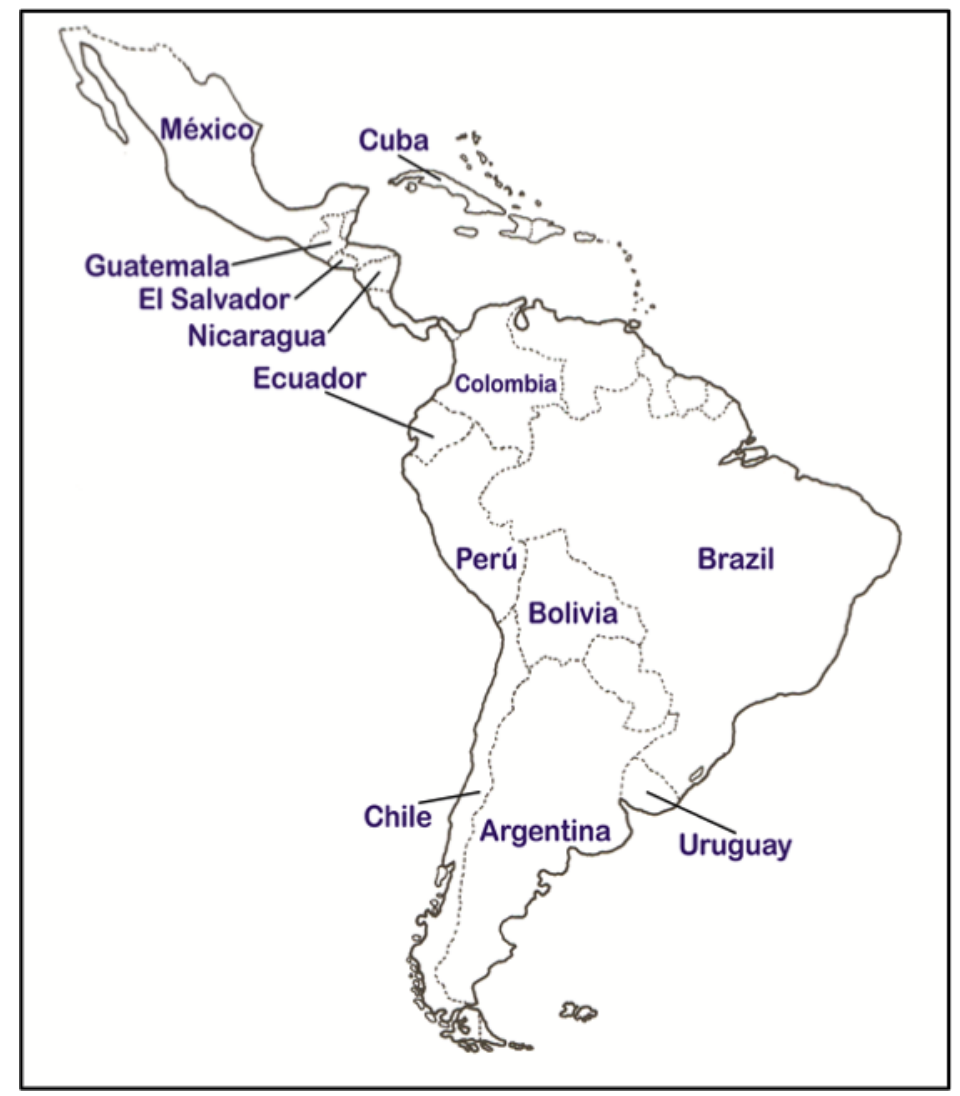

Figure 1. Distribution of arsenic in Latin America.

Argentina.- A compilation of studies conducted in Argentina related to the presence of As in water has been reported in various publications [7-12]; the Chaco-Pampean plain (about 1 million $\mathrm{km}^{2}$ ) is the largest area affected by groundwater As contamination in LA. Arsenic release involves the influx from dissolution of volcanic glass, adsorption of As on $\mathrm{Fe}$ and $\mathrm{Al}$ mineral phases in relatively low $\mathrm{pH}$ zones, and high mobility of As in high $\mathrm{pH}$ zones [9]. In addition, mineralized, hydrothermal zones and hot springs are also major geogenic sources [9]. Co-existence of As and $\mathrm{F}$ in groundwater of the Chaco-Pampean plain has also been remarked [9]. Approximately 88\% of 86 groundwater samples collected in 2007 exceeded the WHO guideline value (see section 5), posing a risk to the population since this water is used for human and livestock consumption. Hydrogeochemical studies have also been performed in the Salí river basin part of the TucumanoSantiagueña hydrogeological province [9]. Arsenic concentrations ranged from 11.4 to $1,660 \mu \mathrm{g} / \mathrm{L}$, with $100 \%$ of the samples above the WHO guideline value. Leaching from pyroclastic materials is favored by high $\mathrm{pH}$ and high bicarbonate waters. The presence of As in surface and groundwaters of the Argentine Altiplano (Puna) and Subandean valleys, which are consumed by 355,000 people, was also evaluated [9]. The concentrations measured in $61 \%$ of the 62 samples collected in an area of 30,000 $\mathrm{km}^{2}$ exceeded the WHO limit. Arsenic occurrence was ascribed to geogenic sources [9].

Most of the studies in Argentina have focused on the sources and processes leading to arsenic enrichment in groundand surface waters, finding that natural sources and geochemical conditions are the ones that affect arsenic occurrence and distribution the most. 
Bolivia.- The presence of As was identified in various areas of Bolivia, mainly related to mining activities, ore deposits, geothermal manifestations, and leaching of volcanic rocks [9,10]. Many of the studies have focused on the Pilcomayo river basin and the Poopó lake basin [9]. Arsenic concentrations were above the WHO guideline value in $95 \%$ of the 41 sampled wells, with seven sites along four rivers reaching $623 \mu \mathrm{g} / \mathrm{L}$. This was related to water contact with alluvial material in lower terrains, arsenopyrite oxidation, and dissolution from volcanic rocks. Groundwater average As concentration was $47 \mu \mathrm{g} / \mathrm{L}$ and ranged from below the detection limit to $200 \mu \mathrm{g} / \mathrm{L}$ in Kondo K, $245 \mu \mathrm{g} / \mathrm{L}$ in Santuario de Quillacas, $152 \mu \mathrm{g} / \mathrm{L}$ in the central region, and $187 \mu \mathrm{g} / \mathrm{L}$ in Pampa Aullagas. The Poopó river contained the highest As concentrations of the sampled surface waters, with $11,140 \mu \mathrm{g} / \mathrm{L}$ in the dry period. Geothermal processes are the main natural sources of As in the area; anthropogenic contamination is related to mine tailings [9]. The importance of mining in Bolivia is reflected in As occurrence; however, natural sources like geothermal processes are also an important source of As contamination in waters.

Brazil.- Mining has been an important source of As in the Iron Quadrangle at the Minas Gerais state [9,10]. Arsenic presence is related to the natural leaching of rocks and soils, as well as mining operations [10]. In the Ribeira valley (southeastern Brazil), $\mathrm{Pb}$ and As contaminated the Ribeira river as a result of $\mathrm{Pb}-\mathrm{Zn}$ ore production and smelting. The Santana district in the Amazon region is also contaminated with As (up to $2.0 \mathrm{mg} / \mathrm{L}$ in some wells) produced from Mn ore benefit [9]. Environmental studies carried out in Brazil have shown that arsenic contamination in surface and groundwaters is mainly related to mineralization and ore exploitation.

Chile.- The area of Atacama Desert, northern Chile, is naturally rich in As; local people have been exposed to this metalloid for more than 4500 years [8]. In the Loa river, As concentrations of up to $2,000 \mu \mathrm{g} / \mathrm{L}$ were measured; these are the result of high evaporation at alkaline $\mathrm{pH}$, and high salinity [9,10]. Arsenic-related health effects from As-rich drinking water pumped from this river were identified as early as 1962. Arsenic is mainly released from volcanic rocks and sulfide ore deposits at the Andean range and mobilized by snowmelts and rain to rivers and springs. At the Camarones valley, drinking water from waterfalls and from the Camarones river contains $48.7 \mu \mathrm{g} / \mathrm{L}$ and 1,252 $\mu \mathrm{g} / \mathrm{L}$ of As, respectively [9]. In the Tarapacá region, As occurrence was ascribed to the presence of volcanic sediments, salt lakes, thermal areas, the predominance of closed basins, and anthropogenic sources [9]. However, As exposure has decreased, and As-related problems have been solved in most of the country [8,9]. The Atacama desert has been identified as one of the oldest places in the world where human exposure to arsenic has occurred undoubtedly due to natural As enrichment. In contrast with other countries where health effects have been caused mainly by groundwater consumption, as in Bangladesh and Argentina, superficial water is the main source of water affecting Chilean inhabitants.

Colombia.- Colombian geology indicates the presence of rocks containing As minerals; nonetheless, few studies have been developed to assess the actual concentrations in water [9]. A review of the occurrence and sources of As in Colombia was reported in 2014 [13]. Information showed that As concentrations in surface and groundwater, related mainly to mining and agriculture, exceeded national standards at some sites. The authors of this review highlight the importance of performing more research on the occurrence, origin and distribution of As in the country [13].

Cuba.- Arsenic has been detected at some sites in Cuba. At Isla de la Juventud, only one spring close to the Delita mine

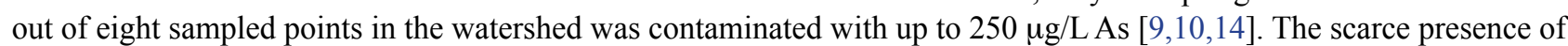
As in Cuba may be due to the geological characteristics of the island, with a predominance of limestones; however, it may reflect the need of additional studies covering the entire territory.

Ecuador.- In Papallacta lake, concentrations of As up to $369 \mu \mathrm{g} / \mathrm{L}$ at the surface and from 289 to $351 \mu \mathrm{g} / \mathrm{L}$ at depth were measured in water $[9,10,15]$. Discharges of geothermal waters to the Tambo river are the main source of As in the lake.

El Salvador.- Arsenic has been detected in the Olomega, Ilopango and Coatepeque lakes with the highest concentration $(4,210 \mu \mathrm{g} / \mathrm{L})$ measured at the Olomega lake. These waters are used by people living on the watersheds $[9,10,16]$. Arsenic in the Ilopango lake is linked to hydrothermal fluids. In the Ahuachapán and Berlin geothermal fields, As from geothermal origin was detected in springs and domestic wells. Arsenic was also found in Las Burras and Obrajuelo aquifers [9]. In the Bajo Lempa region, As presence is related to its occurrence in rocks and geothermal fluids, and probably to an anthropogenic source [17]. The studies developed in El Salvador indicate, thus, that geothermal processes are the main source of As in the country.

Guatemala.- At Mixco, in 2007, a concentration of $15 \mu \mathrm{g} / \mathrm{L} \mathrm{As}$, originated from leaching of volcanic rocks, was measured in the water of a well used for drinking water supply [9,18]. Later, in the area of the Marlin mine, up to $261 \mu \mathrm{g} / \mathrm{L}$ As were measured in wells downgradient from the tailings [9]. A relatively low As concentration was measured in the water from a well at Mixco; however, this concentration is still above WHO drinking water regulatory values and may pose a risk to the population. 
Mexico.- Chronic As poisoning was first identified in 1958 at Comarca Lagunera, northern México [19]. Since then, As has been detected in many areas of the country. Its presence is mainly related to geogenic sources - mineralization, geothermal systems, sorption and release from minerals, salinization - but also to anthropogenic activities in some areas. An overview of As occurrence in groundwater and its possible sources was reported in 2008 [20]. In addition to this, areas with presence of As and F were described in 2013 [21], and another study [22] focused on the occurrence and mechanisms of As enrichment in geothermal zones.

Comarca Lagunera has been one of the most studied areas in Mexico, with groundwater As concentrations of up to 750 $\mu \mathrm{g} / \mathrm{L}[10,23]$. Although various sources have been proposed [24], it was concluded recently that the most probable one is related to extinct hydrothermal activity and sedimentary processes [23]. In addition, intensive groundwater exploitation and dam construction produced the advance of As rich water to the main granular aquifer [24]. Concentrations of As and $\mathrm{F}$ above the Mexican drinking water standards have also been measured at Chihuahua state in northern México $[25,26]$. Hydrogeological and geological interpretations indicated a geogenic source related to the recharge flow coming from mountains presenting arsenopyrite deposits [27]. In mining zones of México where As contamination has been identified, its presence in groundwater is related to natural and/or anthropogenic sources. At Zimapán, Hidalgo, water interaction with As-bearing minerals releases As to the deep fractured limestone aquifer, while the shallow aquifer was contaminated by tailings and infiltration of As-enriched water from smelter stacks [28,29]. In other non-mining areas like the Independencia basin, Guanajuato state, central México, weathering of rhyolites and oxidation of As-bearing minerals result in high As and F concentrations [30]. Hydrogeochemical and isotopic results indicated that As originates from the dissolution of silicates, while F is related to silicates, fluorite dissolution, thermal water, and a long residence time of groundwater. At Juventino Rosas municipality, also in Guanajuato state, hydrogeological and geothermal factors indicated that rhyolite units are the most probable source of As and F [31]. At Los Altos de Jalisco, western Mexico, mean As concentration in drinking water varied from $14.7 \mu \mathrm{g} / \mathrm{L}$ to $262.9 \mu \mathrm{g} / \mathrm{L}$, reaching this value in the city of Mexticacán [32]. Figure 2 represents the oxidation of minerals with As in a Mexican mining zone.

High As concentrations have been detected mainly in Mexican aquifers, many of them corresponding to drinking water sources. However, As-enriched surface and groundwaters are also used for irrigation, and the element has been found in some crops. Arsenic is mainly related to natural sources, although, in mining areas, it is also originated from anthropic activities.

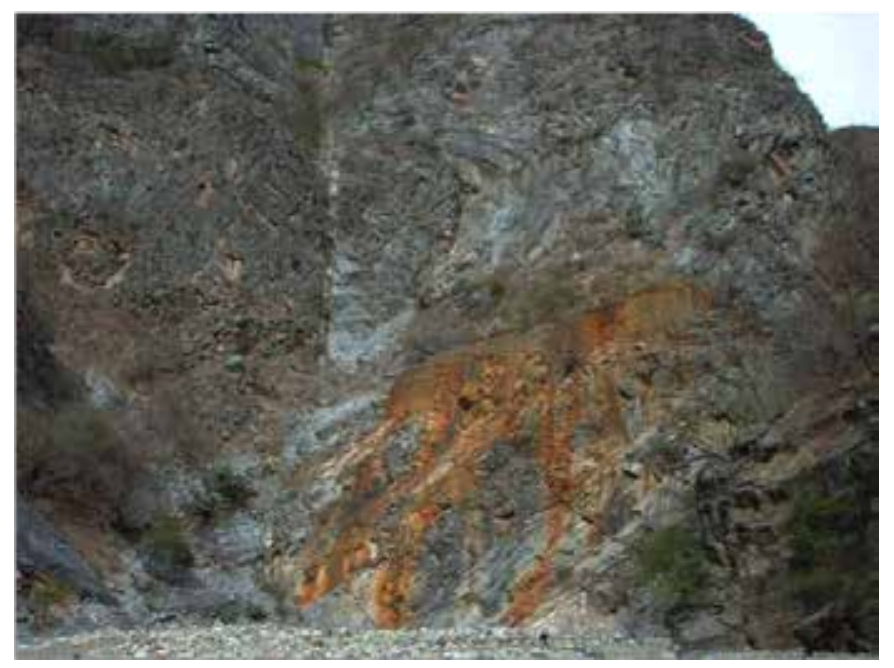

Figure 2. Oxidation of minerals with As in a Mexican mining zone.

Nicaragua.- Geogenic sources contaminated drinking water, from 10 to $122 \mu \mathrm{g} / \mathrm{L}$ As, in the southwestern part of the Sébaco valley. At El Zapote, arsenicosis was detected in people who had been consuming water from a polluted well $(1,320 \mu \mathrm{g} / \mathrm{L}$ As) for two years; this well was closed in 1996. A study developed in 2004 showed that the northern zone of the country presented the highest As contents. At San Juan de Limay, presence of geogenic As was identified in 2005 [9,10,33,34]. The importance of As detection and analysis is shown by the closure of the polluted well at El Zapote, which stopped the exposure of the population to this highly contaminated water.

Peru.- The presence of As has been determined at several sites in Peru, mainly in the Andean region, released by weathering and mining operations. The Locumba river and its tributaries contain up to $1,680 \mu \mathrm{g} / \mathrm{L}$. In the area of the Yucamane volcano, volcanic rocks and pyroclastic materials release As to the Collazas and Salado rivers. In the area of Puno, Andean highlands, As concentrations ranged from 140 to $230 \mu \mathrm{g} / \mathrm{L}$ in the river water. The Rimac river basin has been contaminated by mining activities, leaching of volcanic rocks and ore deposits with up to $1,630 \mu \mathrm{g} / \mathrm{L}$ As that were 
measured in the year 2000 at Puente Santa Rosa [9]. In Peru, as observed in other countries, mineralization and mining activities are significant As sources.

Uruguay.- In the Raigón aquifer, in the southwestern part of the country, As concentrations ranged from 25 to $50 \mu \mathrm{g} / \mathrm{L}$, and were related to continental sediments containing volcanic ash [9,10,35]. The importance of a multidisciplinary approach to determine As in health and in the environment of Uruguay was highlighted [36]. More studies are needed to have a complete overview of As occurrence, sources and possible health impact in Uruguay. However, the concentrations measured so far are lower than those determined in other countries like Argentina and Mexico.

\section{Analytical methods for the analysis of arsenic in Latin America}

The chemical behavior of As depends on environmental conditions such as acidity, oxidation-reduction state of the element, presence of iron, organic matter or other chemical species (e.g., sulfur), etc. Due to the low concentrations at which As may be present in an environment and the chemical behavior of As species, the selection of an adequate analytical technique for As determination will depend on the objectives of the study, the access to the appropriate analytical methodology, the cost of the analyses, and the water matrix. For these reasons, researchers seek analytical techniques with a high degree of precision and accuracy, as well as high sensitivity, which allow measuring concentrations up to the $\mu \mathrm{g} / \mathrm{L}$ level.

A recent work compiles the information from 167 scientific manuscripts identified in the last 18 years, most of them focused on the work done in LA countries [10].

The most widely analytical technique used for As determination is atomic absorption spectrometry (AAS), specifically with the method of sample introduction through hydride generation (HG-AAS) [10]. The detection limit using HG-AAS is about $0.1-0.6 \mu \mathrm{g} / \mathrm{L}[11]$. This technique presents important advantages, such as improved sensitivity and selectivity, and sample salinity does not affect analytical results [11]. Additionally, the HG-AAS technique is a simple methodology that requires relatively inexpensive and very versatile instrumentation, with excellent detection power for total and inorganic As [37]. From 167 identified papers in the last 18 years, 57\% of them (95 papers) referred to the use of AAS as the most used analytical technique in LA for As determination. Another $40 \%$ of these documents are written by researchers from Mexico, 19\% from Argentina and 16\% from Brazil. Other countries that report scientific articles on the quantification of AAS by AAS are Cuba, Ecuador, Peru and Venezuela (the four countries represent 1\%), Uruguay (2\%) and Chile (4\%).

The second most used analytical technique (i.e. $26 \%$ of the aforementioned 167 papers), is inductively coupled plasma spectrometry (ICP), mainly coupled with mass spectrometry ICP-MS [10]. From them, 30\% of publications are from Mexico, 18\% from Brazil and 16\% from Argentina, while Chile and Bolivia report only 4\%. The detection limit reached by this technique is $0.1 \mu \mathrm{g} / \mathrm{L}$, and there is no need of sample preconcentration [11]. In general, ICP-MS and inductively coupled plasma optical emission spectrometry (ICP-OES) are robust and sensitive techniques, but they require very expensive equipment, special facilities and a long and complex training of analysts [37].

Electrochemical analytical techniques are the third most used methodology for As determination [10]. The anodic voltammetry technique has high analytical sensitivity and low cost, and it is easy to use within a concentration interval between 0.1 and $300 \mu \mathrm{g} / \mathrm{L}$ [37]. Argentina, Brazil, Chile, Ecuador and Venezuela reported the use of electrochemical techniques for the determination of As mainly in water and food samples [10].

The fourth most used technique for As determination is UV-VIS molecular spectrometry [10]. The methods based on this analytical technique are simple and economical; however, although sensitivity is high (10 to $50 \mu \mathrm{g} / \mathrm{L})$, accuracy is low [11]. Mexico and Cuba are the main countries that reported the use of this technique for As determination in samples of water and mine tailings [10].

Figure 3 shows the schematic representation of the four main analytical techniques for As determination according to Gürkan et al. [38]. 


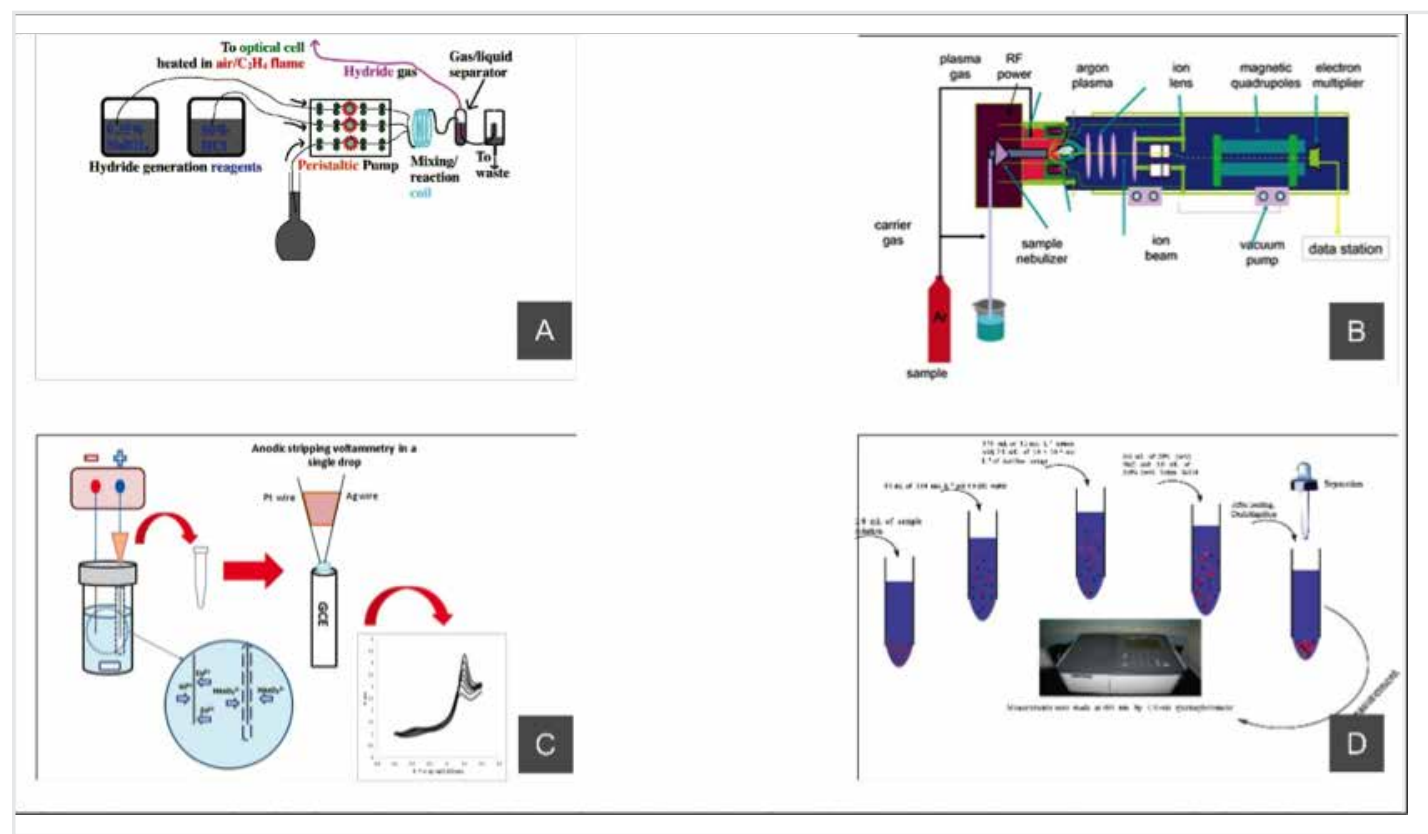

Figure 3. Schematic representation of the four main analytical techniques for As determination: A) HG-AAS, B) ICPMS, C) Anodic voltammetry, D) UV-Vis spectrometry (Gürkan et al., 2015 [38], with permission).

The two most widely used techniques for As speciation are AAS and ICP combined with separation techniques (chromatography), and have been used together or coupled with other analytical techniques (hyphenated techniques) [10]. These coupled techniques are the best option for the determination of arsenical species because of their selectivity, adequate precision, high level of automation and relatively short response times [37]. X-ray fluorescence spectrometry is mainly used for the identification and determination of As in solid samples [10]. In quartziferous sands, the limit of detection reaches $40 \mathrm{mg} / \mathrm{kg}$ (without interferences). Portable equipment can detect up to $60 \mathrm{mg} / \mathrm{kg}$ [11]. The future of this technique, with reference to As determination in waters at the trace level, will be focused mainly through the development of preconcentration methodologies adaptable to laboratory equipment and to on-site determination [11].

Other techniques are neutron activation analysis (NAA) and Surface Plasmon Resonance Nanosensor (SPRN) [10]. NAA is an accurate and sensitive methodology; it has been used for the determination of total As in biological samples (nail, hair and other tissues) with a limit of detection of $0.001 \mu \mathrm{g} / \mathrm{g}$ [11]. SPRN is an autonomous sensor for mapping and monitoring As concentrations in water [39]. This system can be integrated to a portable suitcase, it is inexpensive, and can measure As concentrations below $5 \mu \mathrm{g} / \mathrm{L}$ [39]. However, there are still no results on the application of this method. The ARSOlux Biosensor has been tested in Argentina [40].

\section{Effect of arsenic exposure on human health in Latin America}

The consumption of water with high As concentrations for a prolonged period has been associated with a variety of health problems including issues related to skin, lungs, bladder, and kidneys, as well as neurological disease, cardiovascular disease, perinatal conditions and other benign diseases [10,41-46]. In Argentina, since the beginning of the 20th century, the set of symptoms and signs (clinical manifestations) associated with the consumption of water or food contaminated with As was denominated chronic endemic regional hydroarsenicism (HACRE, from the Spanish acronym, Hidroarsenicismo Crónico Regional Endémico), term that nowadays is being used by many local and regional authors [4,7,46-49].

Arsenic has been classified as a human carcinogen, and inorganic As (iAs) has been related to the development of skin, lung, liver, kidney, bladder and prostate cancer [50]. Prolonged As ingestion from water or food produces characteristic skin lesions such as melanosis, leukomelanosis, and keratosis. Other pathologies include diabetes mellitus, peripheral vascular disease, cardiovascular and respiratory diseases, and a wide variety of clinical manifestations including neurological effects, anemia, leukopenia, liver dysfunction, and high blood pressure. 
To date, most research has examined cancer incidence after exposure to high As concentrations. However, numerous studies have reported various health effects caused by chronic exposure to low concentrations of As [11,46]. More systematic studies are needed to determine the link between As exposure and its related cancer and non-cancer end points [51].

It is known that human biotransformation of iAs generates metabolites of various levels of toxicity (Figure 4), and this is one of the factors that determines the nature and magnitude of its harmful effects. Trivalent species (arsenite (As(III)), monomethylarsonous acid (MMA(III)) and dimethylarsinious acid (DMA(III)) showed to be more toxic than pentavalent species (arsenate $(\mathrm{As}(\mathrm{V}))$, monomethylarsonic acid $(\mathrm{MMA}(\mathrm{V}))$ and dimethylarsinic acid $(\mathrm{DMA}(\mathrm{V}))$, due to their ability to bind to more than two hundred enzymes [52]. MMA(III) is, among all As metabolites, the most toxic metabolic intermediate, while DMA(V) is the least toxic species [53]. However, the quantification of As metabolic intermediates in human biological fluids, based on As oxidation state, is not feasible in many cases due to the lability of trivalent intermediates, which are rapidly oxidized to pentavalent forms. Therefore, the urinary metabolic profile of As is usually considered as the proportions of arsenite, arsenate, monomethylated arsenic (MMA(III) + MMA(V)) and dimethylated arsenic (DMA(III) + DMA(V)). Based on the toxicity of the metabolic intermediates, a protective metabolism of As is the one that shows elevated urinary DMA percentage, and low MMA, As(III) and As(V) percentages. On the contrary, an unfavorable metabolism will be the one that shows an elevated MMA percentage at the expense of a low DMA percentage. There is a wide variability in the relative proportions of urinary iAs metabolites between individuals. Percentages of the major three As species can vary from 5 to $25 \%$ for iAs (As(III) + As(V)), 10 to $30 \%$ for monomethylated metabolites (MMA(III) + MMA(V)), and 50 to $85 \%$ for dimethylated metabolites (DMA(III) + DMA(V)) [54,55]. Genetic factors (presence of polymorphism in genes linked to the metabolism of As) and non-genetic factors (age, gender, nutritional status, social habits, among others) have been studied in relation to their influence on As biotransformation processes and, consequently, on its toxicity [55]. Then, the analysis of the urinary metabolic profile will help predicting individual risk to develop As toxic effects.
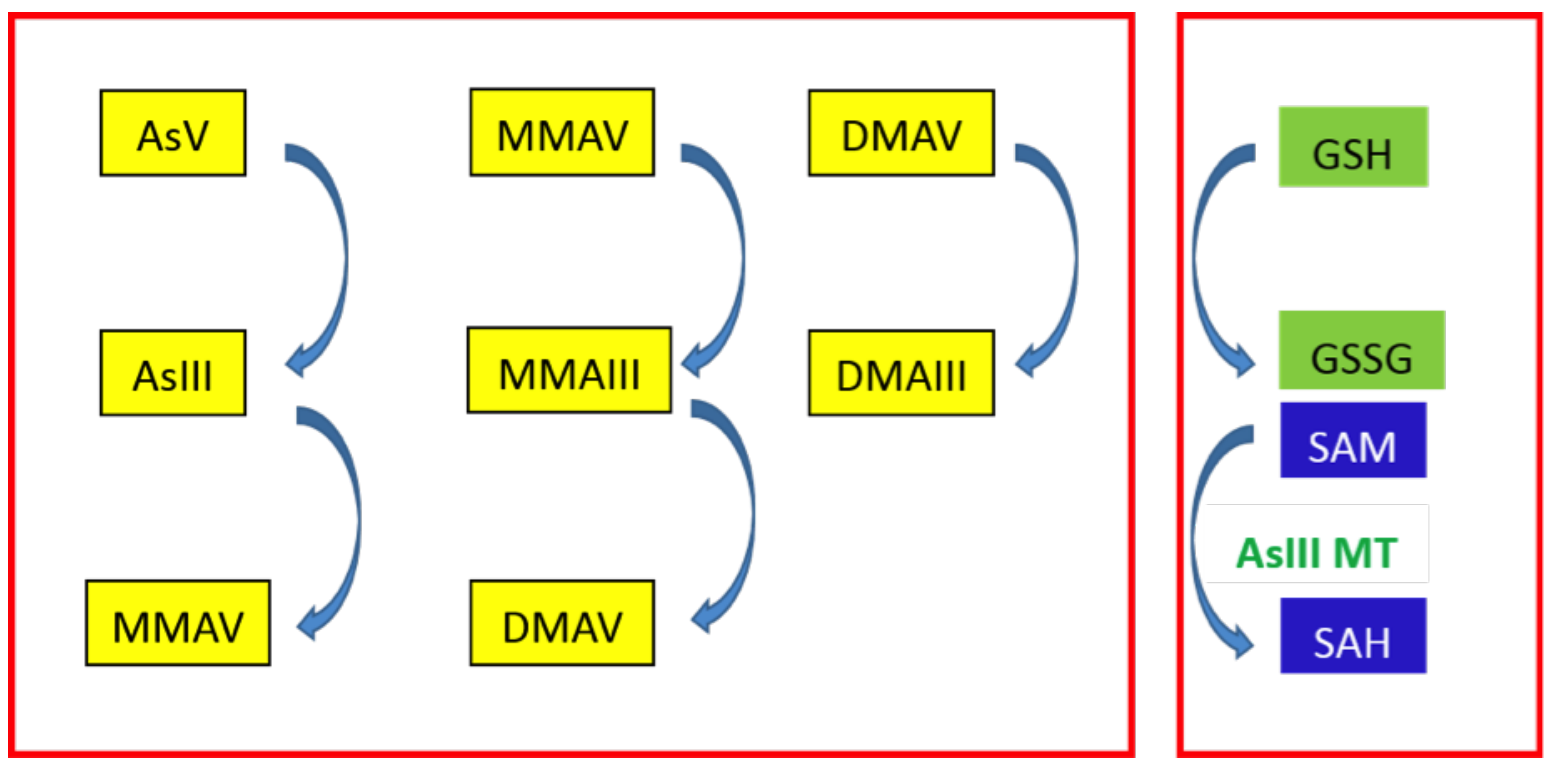

Figure 4. Simplified schematic representation of arsenic biotransformation (2). AsIII: arsenite; AsV: arsenate; AsIII MT: arsenite methyltransferase; DMAIII: dimethylarsinious acid; DMAV: dimethylarsinic acid; GSH: reduced glutathione; GSSG: oxidized glutathione; MMAIII: monomethylarsonous acid; MMAV: monomethylarsonic acid; SAH: S-adenosylhomocysteine; SAM: S-adenosylmethionine.

Even though the presence of As in drinking water has been described in practically all LA countries, studies relating As exposure to health effects are limited to a few ones. Chile, Mexico and Argentina are the countries where most studies on health effects originated from As exposure have been performed. Lung cancer is the most studied adverse effect of As exposure, followed by skin lesions, bladder cancer, effects of early exposure to As, skin cancer, immunotoxicity, kidney cancer, cardiovascular disease and other cancers (liver, prostate, larynx). Sufficient evidence of the association between As exposure and skin, lung and bladder cancers has been reported in Argentina, Chile and Mexico. Studies conducted in Argentina and Chile revealed a clear trend in lung cancer standardized mortality rates and odds ratios with increasing As concentration in drinking water ranging from less than $10 \mu \mathrm{g} / \mathrm{L}$ to a 65 -year average concentration of $200-400 \mu \mathrm{g} / \mathrm{L}$ 
[56,57]. Development of bladder cancer was related to As concentrations of more than $100 \mu \mathrm{g} / \mathrm{L}$, and odds ratios increased significantly with the level of exposure [58,59].

The health effects resulting only from the early exposure to As are difficult to evaluate, since much of the population continues to be exposed until adult life, that is, they do not interrupt their exposure. In that way, the region of Antofagasta, in the north of Chile, has presented a unique pattern of human exposure to As through drinking water. Between 1958 and 1970, As concentration in water was above $800 \mu \mathrm{g} / \mathrm{L}$. In 1970, with the installation of a treatment plant, As concentration in water decreased to values close to $10 \mu \mathrm{g} / \mathrm{L}$. The population born in that area in the period between 1958 and 1970 presents the characteristics of having been early exposed to As. A steep increase in adult mortality due to lung, bladder cancer and kidney cancer was observed in the Chilean population, probably due to in utero and early life exposure to As $[60,61]$.

Evidence of association between As exposure and kidney and liver cancer mortality rates was also reported in Chile and Argentina [46,56,62]. For other types of cancers (prostate, leukemia, brain, colon, breast, larynx, stomach, cervix and endometrium), the evidence in LA countries is scarce or absent [63-64,65]. While the carcinogenicity of As has been confirmed for specific cancers, the mechanisms behind the disease are still not well understood. Several mechanisms have been implicated in the development of As-associated cancers, including the generation of reactive oxygen species (ROS), the inhibition of DNA repair process, alterations in cellular signal transduction and alterations in DNA methylation. No single mechanism has emerged as a key event, and it is likely that iAs exerts carcinogenic effects through multiple mechanisms [61].

According to several studies, conducted mainly in Mexico, an association between As exposure and diabetes seems to occur. However, more studies are needed, specially focusing on the potential mechanisms of As-induced diabetes in humans. Metabolomic studies seem to be a way to discover the biochemical pathways that relate As exposure to diabetes [66]. The available information on the association of exposure to As and cardiovascular disease, liver dysfunction and chronic kidney disease covered a wide range of levels of exposure [67-68,69,70]. However, this information is scarce and inconclusive.

There is no curative treatment for arsenicosis and its clinical manifestations. However, national guidelines for the treatment have been published by the Ministries of Health of Argentina [71], Chile [72] and Peru [73]. In all cases, firstline actions should be focused on avoiding exposure by means of providing alternative sources of safe water. In Chile, the therapeutic decisions are based on urinary As levels [72] and the presence of symptoms. Indications include education, nutritional assessment, urinary As monitoring, antioxidant intake and referral to a specialist, if applicable. In Argentina, the national guidelines recommend avoiding exposure and symptomatic support treatment consisting of healthy protein foods diet [71]. In addition, the guideline indicates that specific symptoms should receive the corresponding treatment measures, as follows: stop smoking in case of chronic bronchitis, topical keratolytics for keratosis, and surgical exeresis for skin tumors [71].

Nevertheless, there are studies that investigate the influence of nutrients on As metabolism, which could, in turn, influence As toxicity. Studies conducted in Mexico and Uruguay investigated whether the differences in dietary intake of selected micronutrients and foods are associated with the metabolism of iAs. The daily intake of methionine, choline, folate, vitamin B12, vitamin $\mathrm{C}, \mathrm{Fe}, \mathrm{Zn}$, Se and $\mathrm{Na}$ was significantly associated with the reduction of \% iAs, and/or \% DMA increase in one study conducted in Mexico [74]. Higher meat and folate consumption, a diet rich in green leafy and red-orange vegetables and eggs contributed to a higher methylation capacity according to the study conducted in Uruguayan children [75].

In conclusion, in LA, research focusing on curative options for chronic As exposure is beginning and it is aligned to the latest international research.

\section{Regulations}

The World Health Organization (WHO) and different environmental agencies such as the United States Environmental Protection Agency and the European Environment Agency, recommend a value of no more than $0.01 \mathrm{mg} / \mathrm{L} \mathrm{of} \mathrm{As} \mathrm{in}$ drinking waters. This value has been adopted in most of the LA countries. In Table 1, the different regulations are displayed, with the concentration limits and the corresponding normative. 


\begin{tabular}{|c|c|c|c|}
\hline Country & Value $(\mu \mathrm{g} / \mathrm{L})$ & Normative & Reference \\
\hline Argentina & 10 (Still under discussion) & CAA (Argentine Food Code) & {$[76]$} \\
\hline Bolivia & 10 & NB 512 & [77] \\
\hline Brazil & 10 & Regulation 2914 & [78] \\
\hline Chile & $\begin{array}{c}10 \text { (a period of } 10 \text { years set to reach } \\
\text { this value) }\end{array}$ & NCh409/1 & [79] \\
\hline Costa Rica & 10 & CAPRE normative, Min. Salud & {$[80,81]$} \\
\hline Colombia & 10 & Resolución 2115 & {$[82]$} \\
\hline Ecuador & 10 & Instituto Ecuatoriano de Normalización & [83] \\
\hline Guatemala & 10 & $\begin{array}{c}\text { COGUANORNGO 29.001, CAPRE } \\
\text { normative }\end{array}$ & {$[80,84]$} \\
\hline Mexico & 25 & NOM-127-SSA1-1994 (modif. 2000) & [85] \\
\hline Nicaragua & 10 & CAPRE normative, INAA 2001 & {$[80,86]$} \\
\hline Peru & $\begin{array}{c}10 \text { (not established period to attain } \\
\text { this maximum) }\end{array}$ & Min. Salud & [87] \\
\hline Uruguay & 20 & $\begin{array}{c}\text { Instituto Uruguayo de Normas } \\
\text { Técnicas }\end{array}$ & [88] \\
\hline Venezuela & 20 & $\begin{array}{c}\text { Ministerio de sanidad y Asistencia } \\
\text { Social }\end{array}$ & [89] \\
\hline
\end{tabular}

Table 1. Limits for As in drinking water in different LA countries

Honduras, El Salvador, Panama and Dominican Republic also follow the CAPRE normative [80]. Additionally, in LA, the As provisional guideline value established by the WHO (i.e., $10 \mu \mathrm{g} / \mathrm{L}$ ) became law in Honduras (1995), El Salvador (1997) and Panama (1999) [9].

\section{Arsenic removal technologies employed in Latin America}

The most used processes for As removal employed in LA are adsorption, chemical precipitation, activated alumina, use of ion exchange resins, membrane technologies, distillation, and coagulation/filtration, which can be used alone or in combination. Use of geoadsorbents, natural materials, iron-based technologies, and solar applications can be also mentioned, especially at small scale or for households. Due to the amount of references on the subject and the multiple materials that can be used, only some references will be included here; the reader can consult references $[9-10,11,21,46,90$ 111] and others therein.

For large and medium plants, coagulation/adsorption/filtration processes have been widely used in LA, with examples in Argentina (Santa Fe and Salta) since the 1990's. One of the most important ones is the patented ArCIS-UNR ${ }^{\circledR}$ process, developed at the Centro de Ingeniería Sanitaria-Universidad Nacional de Rosario, which uses polyaluminum chloride (PAC); it has been applied to real scale in populations up to 10,000 inhabitants. An optimized coagulation/ filtration technology has also been developed by the Instituto Nacional de Tecnología Industrial of Argentina (INTI) and applied to groundwaters of Taco Pozo (Chaco) and Lobos (Buenos Aires) [10,11,46]. In northern Chile, a coagulation technology using $\mathrm{FeCl}_{3}$ has been used since 1970 for plants in small and medium cities with centralized water supply $[10,91]$. In Guatemala, a full-scale treatment plant composed of a coagulation-filtration system with $\mathrm{FeCl}_{3}$ was installed in Mixco (close to the capital city) in 2008 [10]. In 1999, the Instituto Mexicano de Tecnología del Agua (IMTA) adopted a coagulation-flocculation process using $\mathrm{Al}_{2}\left(\mathrm{SO}_{4}\right)_{3}$ as coagulant and other materials (zeolites, clays, bone carbon) as coadjuvants, which was tested in natural waters of Zimapán [10]. In Peru, a treatment plant in the city of Ilo was built in 
1982; initially massive doses of $90 \%$ lime $(\mathrm{CaO})$ were used, but the system was improved by the use of ferric chloride, ferric hydroxide plus sulfuric acid or $\mathrm{Mg}(\mathrm{OH})_{2}$ together with commercial and natural flocculants [10]. In Brazil, a process with PAC and aluminum sulfate with a chlorine preoxidation step has been described [10].

The use of membranes (mainly reverse osmosis processes, RO) is another largely employed alternative for As treatment in large-medium plants [10,46,90,96,97]. Several RO plants have been installed in Argentina (Santa Fe, Cordoba, and La Pampa). The most important ones are those installed in the southern periphery of Buenos Aires City by state-owned company AySA (Aguas y Saneamientos Argentinos), benefiting more than 400,000 inhabitants [10,11,46,49].In northern Chile, desalinization of sea water is a valid option for coastal cities, and RO desalination plants have been installed in Antofagasta and Arica, especially for mining zones [10,46]. In Chihuahua, Mexico, more than 280 small RO plants have been implemented in rural communities; ultrafiltration membranes were also used [10,46]. In 2007, a desalination plant with a capacity of $21,000 \mathrm{~m}^{3} /$ day was installed in Los Cabos, Mexico [46].

On the other hand, in several places of LA, e.g. the Chaco-Pampean plain of Argentina, about 12\% of the population is living in dispersed settlements consisting of less than 50 inhabitants, mostly the poorest members of the regional population. In these places, As is frequently found at high concentrations in water for human consumption. To solve the problem, a large number of commercial adsorbents or natural materials have been tested in different countries $[10,11,46,90,96,97]$. Most of them are materials containing iron or aluminum, but other constituents are also found in them. Aluminum hydrogels, Fe-rich laterites, commercial granular ferric oxide (GFO), granular ferric hydroxides/oxides (GFH/ GFO), hematite, goethite $(\alpha-\mathrm{FeO}(\mathrm{OH}))$, magnetic $\delta$-FeOOH nanoparticles, hydrated $\mathrm{Fe}(\mathrm{III})$ oxide (HFO) nanoparticles supported on polymers, iron oxide coated sand, composite iron matrices, Fe(III)-coated silica sand, metallurgical slags, lime, aluminum sulfate, activated alumina, diatomites, natural clays, bentonites, zeolites, zerovalent iron (ZVI) in the form of $\mu \mathrm{Fe}(0)$ microparticles, Fe fillings, iron wool, nails or packing wire, iron nanoparticles (nZVI)), Fe-Cu bimetallic nanomaterials, manganese greensand, sand-anthracite, manganese oxides, carbon activated with copper sulfate, pisolite, volcanic stones, steel wastes, basic oxygen furnace sludge, ArsenXnp (a commercial As sorbent), etc. can be mentioned, among others $[10,11,46]$. A mixture of an oxidant, activated clays and a coagulant (aluminum sulfate or ferric chloride), patented as ALUFLOC, was developed by CEPIS/SDE/OPS and evaluated at household scale in Puno (Peru), Salta and Tucumán (Argentina) [10,90,96,97,109].

Biomaterials and low-cost organic materials, such as natural hydroxyapatite obtained from charred cow bones, milled bones, bone char modified with nZVI, nacre, shells, chitosan, chitosan beads impregnated with nZVI, dead aquatic macrophytes, dried macroalgae, totora (Schoenoplectus californicus), paja brava (Festuca orthophylla), cellulose, sedges, sorghum biomass, waste biomass, iron-enriched activated carbon from lignite, maracuya shell (some modified with $\mathrm{Fe}(\mathrm{III})$ ), a bioadsorbent taken from passion fruit, a bioadsorbent obtained from orange albedo coated with Fe(III), etc., were also tested [10]. Bacteria like Pseudomonas aeruginosa, Microcystis novacekii and sulfate reducing bacteria (SRB) were reported to be used for As removal. Phytoremediation with aquatic macrophytes such as water hyacinth (Eichhornia crassipes), lesser duckweed (Lemna minor) and valdivia duckweed (Lemna valdiviana) were also assayed [10,90].

Another cost-effective, environmental-friendly treatment technology for As removal is the use of horizontal subsurface flow constructed wetlands (SSFCW). In Chile, SSFCW constructed with zeolite, limestone and cocopeat; in Mexico, SSFCW containing an iron oxide substrate (tezontle) with two plant species (Zantedeschia aethiopica and Anemopsis californica) and without them were evaluated. Two Cyperaceae species, Schonoeplectous americanus and Eleocharis macrostachya were also studied in a SSFCW prototype system [10,90]. Other studies optimized As removal by capacitive deionization $[93,96]$ and in-line electrochlorination to produce hypochlorous acid for oxidation and coprecipitation of As and $\mathrm{Fe}[112]$.

Mining effluents containing As have been especially considered in LA. In Brazil, several works reported As precipitation with trivalent iron salts and lime $\left(\mathrm{CaO}\right.$ or $\left.\mathrm{Ca}(\mathrm{OH})_{2}\right)$, and with $\mathrm{Al}-\mathrm{Fe}$ (hydr)oxides, scorodite $\left(\mathrm{FeAsO} \mathrm{A}_{4} \cdot 2 \mathrm{H}_{2} \mathrm{O}\right)$ formation from industrial solutions, and $\mathrm{Mn}_{3}\left(\mathrm{AsO}_{4}\right)_{2} \cdot 4 \mathrm{H}_{2} \mathrm{O}$ formation from nanosized birnessite (Mn(IV)). Coprecipitation by the use of selective coagulants/flocculants has been also studied to be applied in gold mining and other effluents [10,46,90]. In Chile, a plant for the treatment of mining effluents for dusts from copper smelters in the Chuquicamata and Ministro Hales minesand was constructed, stabilizing As as scorodite with ferric sulfate [46]. Byproducts of the iron mining industry, such as magnetite, hematite, iron hydroxides and/or foundry slag, have been also used to remove As [46]. Desalination plants applying RO processes have been used in Chile for the treatment of mining wastewaters [46].

Photochemical technologies were also important methods for As removal in LA. Photooxidation of As(III) with germicidal lamps $(\lambda=253.7 \mathrm{~nm})$ and $\mathrm{H}_{2} \mathrm{O}_{2}$ addition, a combined technology employing $\mathrm{UV} / \mathrm{H}_{2} \mathrm{O}_{2}$ and adsorption in columns filled with $\mathrm{TiO}_{2}$ and GFH, and use of ZVI and nZVI plus solar irradiation have been tested $[10,46,90]$. The Solar Oxidation and Removal of As (SORAS) technology, a very simple process for poor, isolated populations, used with partial success in Bangladesh and India, was modified and tested in LA. This method consists in putting water in transparent 
PET bottles and irradiating it with sunlight. This is done in the presence of small amounts of dissolved iron, causing the precipitation of iron(III) (hydr)oxides, As(III) oxidation and As(V) adsorption; clear water is obtained by further decantation or filtration (Figure 5). The addition of small amounts of citric acid - as drops of lemon juice - enhances the effectiveness of As removal due to the coupling of photo-Fenton processes. Because groundwaters in most regions of LA do not have enough iron to make the SORAS technology efficient, iron has to be externally added through some natural Fe-containing minerals or ZVI in different forms (iron wool, packing wire or nZVI). The method has been tested in laboratory waters and natural well waters of Argentina, Bolivia, Chile, Costa Rica, Mexico and Peru [10,46,90].
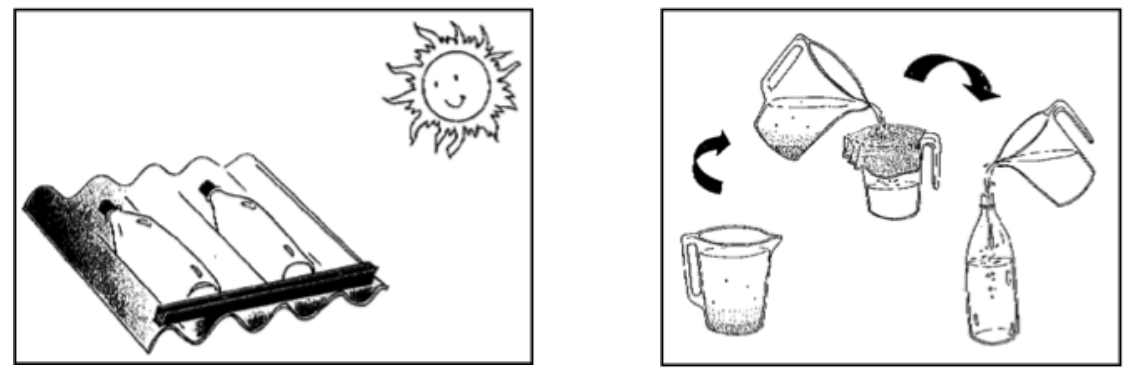

Figure 5. Schematic representation of the SORAS technology.

$\mathrm{TiO}_{2}$ heterogeneous photocatalysis is also a promising emergent technology which allows the simultaneous oxidation of As(III) and removal of organic pollutants, toxic metals and microbiological contamination. An iron source should be added to retain As on a solid surface. PET plastic bottles have been impregnated with $\mathrm{TiO}_{2}$ and used to remove As in Argentina and Brazil. Reduction of $\mathrm{As}(\mathrm{V})$ and $\mathrm{As}(\mathrm{III})$ over $\mathrm{TiO}_{2}$ under $\mathrm{UV}$ light has been also attained in deoxygenated suspensions, with identification of $\mathrm{As}(0)$ and arsine $\left(\mathrm{AsH}_{3}\right)$ [10-1112,46,90,95,96,110].

A paper regarding toxicity of $\mathrm{As}(\mathrm{V})$ solutions has been also evaluated after treatment with nZVI with the AMPHITOX bioassay [113].

\section{Conclusions}

The contamination of surface and groundwaters with As in LA is a relevant problem for the region due to its dramatic consequences on health. Arsenic presence has been identified in many LA countries in a range of concentrations and originated from various sources, although in most of the locations it comes from natural sources. The Chaco-Pampean plain in Argentina is the largest area affected by groundwater As contamination. Research on the chemical and hydrogeological processes of As release and mobilization has been also developed in Mexico, Chile, Bolivia, Peru and Nicaragua. In most of the contaminated areas, As originates from geogenic sources, mainly volcanic rocks, hydrothermal fluids and Asbearing minerals. However, anthropogenic sources are also present in certain zones, most of them as a result of mining operations and, in some cases, related to agriculture. Mining is indeed the main As source in Brazil. It has been found that the element is in the $\mathrm{As}(\mathrm{V})$ form in most locations.

Regarding analytical methods on As determination, 167 papers in scientific journals have been identified in the last 18 years in LA. The most widely used analytical methodologies are AAS (57\%), specifically HG-AAS, and ICP (27\%), mainly coupled with MS. Electrochemical methods have been applied in Chile, Brazil and Argentina. UV-VIS spectrometry has been used mainly in Cuba and Mexico. XRF spectrometry, principally for solid samples, has been used in Mexico, Cuba, Brazil, Argentina, and Chile. Other methodologies are INAA, SPRN and the ARSOlux Biosensor. In LA, good scientific and infrastructure capacity for the analytical determination of As in various matrices is available.

Because the As problem has a great impact on health in LA, and its presence has also been reported in different matrices (food, hair, blood and bones), it is important to emphasize the quality assurance of the reported results. Therefore, it is suggested that a section dedicated to the interferences and the analytical quality control used for the quantification of this metalloid be added to the scientific publications, regardless of the analytical method used. This quality control could include some of the parameters established by ISO / IEC 17025: 2017 for analytical validation (uncertainty, repeatability and reproducibility, robustness), as well as the certified reference materials used.

Concerning effects on health, lung cancer is the most studied adverse effect of As exposure, followed by skin lesions, bladder cancer and the effects of early exposure to As. Chile is the country with the largest number of scientific publications related to the effects of As on health, followed by Mexico and Argentina, where studies on As exposure and cancer development are well described. Evidence of association between As exposure and kidney and liver cancer 
mortality rates was also reported in Chile and Argentina. For other types of cancers (prostate, leukemia, brain, colon, breast, larynx, stomach, cervix and endometrium), the evidence is scarce or absent. While the carcinogenicity of As has been confirmed for several cancers, the mechanisms behind the disease are still not well understood, and, therefore, more well-designed studies are needed in that area. According to several studies, conducted mainly in Mexico, an association between As exposure and diabetes seems to occur; however, more studies should be conducted. In that way, metabolomic studies could help find some answers. The information available on the association of exposure to As and cardiovascular disease, liver dysfunction and chronic kidney disease covered a wide range of levels of exposure, but this information is still partial, scarce and inconclusive.

Investigations on As health effects are limited to Argentina, Chile and Mexico and, even in these countries, studies are scarce, scattered and consider different degrees of exposure, which hinders the comparison or integration into a metaanalysis. In Argentina, an epidemiological study of national scope started in 2019; it includes an analysis of morbidity and mortality due to cancers associated with the exposure to As through water ingestion. This study could be extended to other LA countries.

Arsenic removal from water can proceed through adequate treatments. Methods for large and medium plants have been implemented in several places using the most common technologies (coagulation-precipitation and RO). Other technologies use a very large number of adsorbing materials (natural geological materials, iron oxides and hydroxides, calcite, clays, etc.). Sorption agents coming from plants and animal residues have been tested especially for small communities, disperse settlements or individual households of low economical resources, where simple and economical equipment that can be easily handled and maintained by the population is required. Procedures using zerovalent iron from diverse materials are affordable and easy to operate and maintain, and sunlight may be used to improve their effectiveness. Phytoremediation and wetland construction are also promising technologies.

In addition, the LA experience gives valuable information that could be used to solve the As problem in other regions of the world, especially in countries of Asia where the first option is to find other water sources not contaminated with As. In all cases, water composition and socioeconomic features should be carefully considered for selecting the technology.

Although there are several sustainable solutions developed by local researchers, authorities, industries and international agencies have not practically developed any financial and technical cooperation action for mitigating the As problem in isolated rural and periurban LA populations, and As exposure has not been yet solved due to operation, social, and economic problems. In addition, there are zones still lacking As-free water options. Thus, much R\&D work, together with political actions, should be undertaken in the region.

\section{Acknowledgments}

This work was supported by Agencia Nacional de Promoción Científica y Tecnológica (ANPCyT) from Argentina under PICT-2015-0208, and by BioCriticalMetals - ERAMIN 2015 grants. We appreciate the support of Olivia Cruz, Alejandra Aguayo, Nora E. Ceniceros Bombela and Blanca X. Felipe Martínez, from the Geophysics Institute at UNAM, who helped with the bibliographic search process.

\section{References}

[1] Argos, M., Ahsan, H., Graziano, J.H., 2012. Arsenic and human health: epidemiologic progress and public health implications. Rev Environ Health 27, 191-195.

[2] Lage, C.R., Nayak, A., Kim, C.H., 2006. Arsenic ecotoxicology and innate immunity. Integr Comp Biol 46, 10401054.

[3] US Environmental Protection Agency, 2012.Arsenic in Drinking Water.US Environmental Protection Agency, United States.

[4] Litter, M.I., 2010. La problemática del arsénico en la Argentina: el HACRE. Rev Soc Argent Endocrinol Ginecol Reprod (SAEGRE) 17, 5-10.

[5] Murcott, S., 2012. Arsenic Contamination in the World - an International Sourceboo.IWA Publishing, London, UK.

[6] McCarty, K.M., Hanh, H.T., Kim, K.W., 2011.Arsenic geochemistry and human health in South East Asia. Rev Environ Health 26 (1), 71-78. 
[7] Bundschuh A, Pérez Carrera M, Litter MI (Eds.), 2008. Distribución del arsénico en la región Ibérica e Iberoamericana. CYTED, ISBN 978-84-96023-61-1.

[8] Figueiredo, B.R., Litter, M.I., Silva, C.R., Mañay, N., Londono, S.C., Rojas, A.M., Garzón, C., Tosiani, T., Di Giulio, G.M., De Capitani, E.M., dos Anjos, J.Â.S.A., Angélica, R.S., Morita, M.C., Paolielo, M.M.B., Cunha, F.G., Sakuma, A.M., Licht, O.A., 2010. Medical geology: a regional synthesis. In: Selinus, O., Finkelman RB, Centeno JA (eds) Medical Geology: A Regional Synthesis. Medical geology studies in South America. Book Series International Year of Planet Earth, Springer Netherlands, pp. 79-106.

[9] Bundschuh, J., Litter, M.I., Parvez, F., Román-Ross, G., Nicolli, H.B., Jean, J.-S., Liu,C.-W., López, D., Armienta, M.A., Gómez Cuevas, A., Cornejo, L., Cumbal, L., Guilherme, L.R.G., Toujaguez, R., 2012. One century of arsenic exposure in Latin America: A review of history and occurrence from 14 countries, Sci. Total Environ. 429, 2-35.

[10] Litter M.I., Armienta M.A., Villanueva Estrada R.E., Villaamil Lepori E., Olmos V., Arsenic in Latin America, Part I, In: Arsenic in Drinking Water and Food, S. Srivastava (Ed.). Springer, pp. 71-112.

[11] Litter, M.I., Botto, L., Difeo, G., Farfán Torres, E.M., Frangie, S., Herkovits, J., Ingallinella, A.M., Olmos, V., Savio, M., Schalamuk, I., Taylor, S., Berardozzi, E., García Einschlag, F.S., Arsénico en agua.Informe final. 2018. Grupo ad hoc arsénico en agua, Red de Seguridad Alimentaria, Consejo Nacional de Investigaciones Científicas y Técnicas. ISSN 2618-2785. DOI: 10.13140/RG.2.2.29582.20800. rsa.conicet.gov.ar/wp-content/uploads/2018/08/InformeArsenico-en-agua-RSA.pdf. (Accessed November 2018).

[12] Litter, M.I., Ingallinella, A.M., Olmos, V., Savio, M., Difeo, G., Botto, L., Farfán Torres, E.M., Taylor, S., Frangie, S., Herkovits, J., Schalamuk, I., González, M.J., Berardozzi, E., García Einschlag, F.S., Bhattacharya, P., Ahmad, A., Arsenic in Argentina: technologies for arsenic removal from groundwater sources, investment costs and waste management practices, Sci. Total Environ., 690 (2019), pp. 778-789.

[13] Alonso, D.L., Latorre, S., Castillo, E., Brandão, P.F.B. 2014. Environmental occurrence of arsenic in Colombia: A review, Environ. Pollut. 186:272-281.

[14] Toujague, R., Leonarte, T., Reyes Verdecia, A., Miravet, B.L., Leal, R.M. 2003. Arsénico y metales pesados en aguas del área Delita, Isla de la Juventud, Cuba, Ciencias de la Tierra y el Espacio 4:27-33.

[15] Cumbal, L.H., Bundschuh, J., Aguirre, V., Murgueitio, E., Tipán, I., Chávez, C. 2009. The origin of arsenic in sediments from Papallacta lake area in Ecuador. In: Bundschuh, J., Armienta, M.A., Birkle, P., Bhattacharya, P., Matschullat, J., Mukherjee, A.B. (eds) Natural arsenic in groundwaters of Latin America, CRC Press, London, pp. 81-90.

[16] López, D.L., Bundschuh, J., Birkle, P., Armienta, M.A., Cumbal, L., Sracek, O., Cornejo, L., Ormachea, M. 2012. Arsenic in volcanic geothermal fluids of Latin America, Sci. Total Environ. 429:57-75.

[17] López, D.L., Ribó, A., Quinteros, E., Mejía, R., López, A., Orantes, C. 2014. Arsenic in soils, sediments, and water in area with high prevalence of chronic kidney disease of unknown etiology. In: Litter, M.I., Nicolli, H.B., Meichtry, J.M., Quici, N., Bundschuh, J., Bhattacharya, P., Naidu, R. (eds) One Century of the Discovery of Arsenicosis in Latin America (1914-2014), CRC Press, London, pp. 251-254.

[18] Garrido Hoyos, S.E., Avilés Flores, M., Rivera Huerta, M.L., Nájera Flores, M.C. 2007. Diagnóstico de la presencia de arsénico en agua de pozo, Mixco, Guatemala. Final report TC-0711.3. Jiutepec, Mexico: Instituto Mexicano de Tecnología del Agua.

[19] Cebrián, M.E., Albores, A., García-Vergas, G., Del Razo, L.M. 1994. Chronic arsenic poisoning in humans: The case of Mexico. In: Nriagu, J.O. (ed.) Arsenic in the environment Part II Wiley, New York, pp. 93-107.

[20] Armienta, M.A., Segovia, N. 2008. Arsenic and fluoride in the groundwater of Mexico, Environ.Geochem. Health 30:345-353.

[21] Alarcón-Herrera, M.T., Bundschuh, J., Nath, B., Nicolli, H.B., Gutierrez, M., Reyes-Gomez, V.M., Nunez, D., Martín-Dominguez, I.R., Sracek, O., 2013. Co-occurrence of arsenic and fluoride in groundwater of semi-arid regions in Latin America: Genesis, mobility and remediation, J. Hazard. Mater. 262:960-969.

[22] Birkle, P., Bundschuh, J., Sracek, O. 2010, Mechanisms of arsenic enrichment in geothermal and petroleum reservoirs fluids in Mexico, Water Res. 44:5605-5617. 
[23] Boochs, P.W., Billib, M., Gutiérrez, C., Aparicio, J. 2014, Groundwater contamination with arsenic, RegiónLagunera, México. In: Litter, M.I., Nicolli ,H.B., Meichtry, J.M., Quici, N., Bundschuh, J., Bhattacharya, P., Naidu, R. (eds) One Century of the Discovery of Arsenicosis in Latin America (1914-2014), CRC Press, London, pp. 132-134.

[24] Ortega-Guerrero, A. 2017. Evaporative concentration of arsenic in groundwater: health and environmental implications, La Laguna Region, Mexico, Environ. Geochem. Health 39:987-1003.

[25] Espino-Valdés, M.S., Barrera-Prieto, Y., Herrera-Peraza, E. 2009. Arsenic presence in North section of MeoquiDelicias aquifer of State of Chihuahua, Mexico, Tecnociencia Chihuahua 3: 8-17.

[26] Reyes-Gómez, V., Alarcón, M., Gutiérrez, M., Nuñez, D. 2013. Fluoride and Arsenic in an Alluvial Aquifer System in Chihuahua, Mexico: Contaminant Levels, Potential Sources, and Co-occurrence, Water Air Soil Pollut. 224:14331448 .

[27] Mar Camacho, M. L., Gutierrez, M., Alarcon-Herrera, M.T., Villalba, M.L., Deng, S. 2011. Occurrence and treatment of arsenic in groundwater and soil in northern Mexico and southwestern USA, Chemosphere 83:2011-225.

[28] Armienta, M.A., Villaseñor, G., Rodriguez, R., Ongley, L.K., Mango, H. 2001. The role of arsenic-bearing rocks in groundwater pollution at Zimapán Valley, México, Environ.Geol. 40:571-581.

[29] Sracek, O., Armienta, M.A., Rodríguez, R., Villaseñor, G. 2010. Discrimination between diffuse and point sources of arsenic at Zimapán, Hidalgo state, Mexico, J. Environ. Monit. 12:329-337.

[30] Ortega-Guerrero, A., 2009. Presencia, distribución, hidrogeoquímica y origen de arsénico, fluoruro y otros elementos traza disueltos en agua subterránea, a escala de cuenca hidrológica tributaria de Lerma-Chapala, México, Rev. Mex. Cienc. Geol. 26:143-161.

[31] Morales-Arredondo, I., Rodríguez, R., Armienta, M.A., Villanueva-Estrada, R.E. 2016. The origin of groundwater arsenic and fluorine in a volcanic sedimentary basin in central Mexico: a hydrochemistry hypothesis, Hydrogeol. J. 24:1029-1044.

[32] Hurtado-Jiménez, R., Gardea-Torresdey, J.L. 2006. Contamination of drinking water supply with geothermal arsenic in Los Altos de Jalisco, Mexico, pp. 179-190. In: Bundschuh, J., Armienta, M.A., Birkle, P., Bhattacharya, P., Matschullat, J., Mukherjee, A.B. (eds) Natural arsenic in groundwaters of Latin America, CRC Press, London, pp. 179-190.

[33] Altamirano Espinoza, M., Bundschuh, J. 2009. Natural arsenic groundwater contamination of the sedimentary aquifers of southwestern Sébaco valley, Nicaragua, Bundschuh, J., Armienta, M.A., Birkle, P., Bhattacharya, P., Matschullat, J., Mukherjee, A.B. (eds) Natural arsenic in groundwaters of Latin America, CRC Press, London, pp. $109-122$.

[34] Armienta, M.A., Rodríguez, R., Segovia, N., Monteil, M. 2010. Medical Geology in Mexico, Central America and the Caribbean. In: Selinus, O., Finkelman, R.B., Centeno, J.A. (eds) Medical geology a Regional Synthesis, Springer, N.Y. pp. 59-78.

[35] Guérèquiz, R., Mañay, N., Goso-Aguilar, C., Fernández-Turiel, J.L., García-Valles, M. 2009. Environmental risk assessment of arsenic in the Raigon aquifer. Uruguay. Biologist (Lima) 7. Special issue. C0130.

[36] Mañay, N., Pistón, M., Goso, C. 2014. Arsenic environmental and health issues in Uruguay: A multidisciplinary approach. In: Litter, M.I., Nicolli, H.B., Meichtry, J.M., Quici, N., Bundschuh, J., Bhattacharya, P., Naidu, R. (eds) One Century of the Discovery of Arsenicosis in Latin America (1914-2014), CRC Press, London, pp. 485-487.

[37] Litter, M.I.; Armienta, M.A.; Farías, S.S. (Ed.). 2009. Iberoarsen. Metodologías analíticas para la determinación y especiación de arsénico en aguas y suelos, Editorial Programa Iberoamericano de Ciencia y Tecnología para el Desarrollo, CYTED.

[38] Gürkan, R., Kir, U., Altunay, N. 2015. Development of a simple, sensitive and inexpensive ion-pairing cloud point extraction approach for the determination of trace inorganic arsenic species in spring water, beverage and rice samples by UV-Vis Spectrophotometry. Food Chemistry. 180: 32-41.

[39] Salinas, S., Mosquera, N., Yate, L., Coy, E., Yamhure, G., González, E., 2014. Surface plasmon resonance nanosensor for the detection of arsenic in water. Sensors and Transducers. 183 (12): 97-102. 
${ }^{[40]}$ K. Siegfried, S. Hahn-Tomer, A. Koelsch, E. Osterwalder, J. Mattusch, H.-J. Staerk, J.M. Meichtry, G.E. De Seta, F.D. Reina, C. Panigatti, M.I. Litter, H. Harms, Introducing Simple Detection of Bioavailable Arsenic by Using the ARSOlux Biosensor in Rafaela, Santa Fe Province in Argentina, Int. J. Environ. Res. Public Health 12 (2015) 5465-5482. doi:10.3390/ijerph120x0000x, http://www.mdpi.com/1660-4601/12/5/5465.

[41] Brouwer, O.F., Onkenhout, W., Edelbroek, P.M., de Kom, J.F., de Wolff, F.A., Peters, A.C., 1992.Increased neurotoxicity of arsenic in methylenetetrahydrofolate reductase deficiency. Clin. Neurol.Neurosurg. 94, 307-310.

[42] Chen, C.J., Chen, C.W., Wu, M.M., Kuo, T.L. 1992.Cancer potential in liver, lung, bladder and kidney due to ingested inorganic arsenic in drinking water. Br. J. Cancer 66, 888-892.

[43] Hopenhayn-Rich, C., Biggs, M.L., Fuchs, A., Bergoglio, R., Tello, E.E., Nicolli, H., Smith, A.H., 1996. Bladder cancer mortality associated with arsenic in drinking water in Argentina. Epidemiology 7, 117-124.

[44] Rahman, M., Tondel, M., Ahmad, S.A., Chowdhury, I.A., Faruquee, M.H., Axelson, O., 1999. Hypertension and arsenic exposure in Bangladesh. Hypertension 33, 74-78.

[45] Smith, A.H., Goycolea, M., Haque, R., Biggs, M.L.., 1998. Marked increase in bladder and lung cancer mortality in a region of Northern Chile due to arsenic in drinking water. Am J Epidemiol 147, 660-669.

[46] Litter M.I., Armienta M.A., Villanueva Estrada R.E., Villaamil Lepori E., Olmos V., Arsenic in Latin America, Part I, In: Arsenic in Drinking Water and Food, S. Srivastava (Ed.). Springer, pp. 113-181.

[47] Ayerza, A. Arsenicismo regional endémico (keratodermia y melanodermia combinadas) (continuación). Bol. Acad. Medicina 1917; 2-3:41-55.

[48] Gerstenfeld, S., Jordán, A., Calli, R., Farías, P., Malica, J., Gómez Peña, M.. L., Aguirre, L., Salvatierra, M., Leguizamón, E., Coronel, C., Flores Ivaldi, E., 2012. Determinación de zonas de riesgo al agua arsenical y prevalencia de HACRE en Villa Belgrano, Tucumán, Argentina. Rev. Argent. Salud Pública, 24-29.

[49] Bardach, A.E., Ciapponi, A., Soto, N., Chaparro, M.R., Calderon, M., Briatore, A., Cadoppi, N., Tassara, R., Litter, M.I. 2015.Epidemiology of chronic disease related to arsenic in Argentina: A systematic review. Sci. Total Environ. 538:802-816.

[50] International Agency for Research on Cancer (IARC).2012. Arsenic, metals, fibres, and dusts. Vol 100 C. A review of human carcinogens. IARC Monographs on the Evaluation of Carcinogenic Risks to Humans, World Health Organization. Lyon (France). http://publications.iarc.fr/Book-And-Report-Series/Iarc-Monographs-On-TheEvaluation-Of-Carcinogenic-Risks-To-Humans/Arsenic-Metals-Fibres-And-Dusts-2012. (Accessed April 2018).

[51] Agency for Toxic Substances and Disease Registry (ATSDR). 2013. Course: Arsenic Toxicity. Environmental Health and Medicine Education. https://www.atsdr.cdc.gov/ csem/csem.asp?csem=1\&po=1.1. (Accessed October 2018).

[52] Khairul, I., Wang, Q.Q., Jiang, Y.H., Wang, C., Naranmandura, H. 2017.Metabolism, toxicity and anticancer activities of arsenic compounds. Oncotarget. 4;8(14):23905-23926.

[53] Styblo, M., Del Razo, L.M., Vega, L., Germolec, D.R., LeCluyse, E.L., Hamilton, G.A., Reed, W., Wang, C., Cullen, W.R., Thomas, D.J. 2000. Comparative toxicity of trivalent and pentavalent inorganic and methylated arsenicals in rat and human cells. Arch. Toxicol., 74: 289-299.

[54] Bailey, K.A., Wu, M.C., Ward, W.O., Smeester, L., Rager, J.E., García-Vargas, G., Del Razo, L.M., Drobná, Z., Stýblo, M., Fry, R.C. 2013. Arsenic and the epigenome: interindividual differences in arsenic metabolism related to distinct patterns of DNA methylation. J Biochem. Mol. Toxicol. 27:106-115.

[55] Olmos, V., Navoni, J.A., Calcagno, M.L., Sassone, A.H., VillaamilLepori, E.C. 2015. Influence of the level of arsenic exposure on its metabolic profile, in a population from an endemic area of Argentina. Association with the presence of the T860C polymorphism in arsenic 3-Methyl Transferase Gene. Hum. Exp. Toxicol. 34: 170-178.

[56] Hopenhayn-Rich, C., Biggs, M.L., Smith, A.H. 1998.Lung and kidney cancer mortality associated with arsenic in drinking water in Córdoba, Argentina. Int. J. Epidemiol. 27:561-9.

[57] Ferreccio, C., González, C., Milosavjlevic, V., Marshall, G., Sancha, A.M., Smith, A.H. 2000. Lung cancer and arsenic concentrations in drinking water in Chile. Epidemiology 11:673-679. 
[58] Smith, A.H., Goycolea, M., Haque, R., Biggs, M.L. 1998.Marked increase in bladder and lung cancer mortality in a region of Northern Chile due to arsenic in drinking water. Am. J. Epidemiol. 147:660-9.

[59] Ferreccio, C., Yuan, Y., Calle, J., Benitez, H., Parra, R.L., Acevedo, J., Smith, A.H., Liaw, J., Steinmaus, C. 2013. Arsenic, Tobacco Smoke, and Occupation Associations of Multiple Agents with Lung and Bladder Cancer. Epidemiology 24:898-905.

[60] Steinmaus, C., Ferreccio, C., Acevedo, J., Yuan, Y., Liaw, J., Durán, V., Cuevas, S., García, J., Meza, R., Valdés, R., Valdés, G., Benítez, H., VanderLinde, V., Villagra, V., Cantor, K.P., Moore, L.E., Perez, S.G., Steinmaus, S., Smith, A.H. 2014. Increased lung and bladder cancer incidence in adults after in utero and early-life arsenic exposure.Cancer Epidemiol. Biomarkers Prev. 23:1529-1538.

[61] Bailey, K.A., Smith, A.H., Tokar, E. J., Graziano, J.H., Kim, K.W., Navasumrit, P., Ruchirawat, M., Thiantanawat, A., Suk, W.A., Fry, R.C. 2016.Mechanisms Underlying Latent Disease Risk Associated with Early-Life Arsenic Exposure: Current Research Trends and Scientific Gaps. Environ. Health.Persp. 124:170-175.

[62] Ferreccio, C., Smith, A.H., Durán, V., Barlaro, T., Benítez, H., Valdés, R., Aguirre, J.J., Moore, L.E., Acevedo, J, Vásquez, M.I., Pérez, L., Yuan, Y., Liaw, J., Cantor, K.P., Steinmaus, C. 2013b. Case-control study of arsenic in drinking water and kidney cancer in uniquely exposed Northern Chile. Am. J. Epidemiol., 178(5):813-8.doi: 10.1093/ aje/kwt059.

[63] Liaw, J., Marshall, G., Yuan, Y., Ferreccio, C., Steinmaus, C., Smith. A.H. 2008. Increased childhood liver cancer mortality and arsenic in drinking water in northern Chile. Cancer Epidemiol. Biomarkers Prev. 17:1982-1987.

[64] Molina, R., Schulz, C., Bernardos, J., Dalmaso, M. 2014. Association between arsenic in groundwater and malignant tumors in La Pampa, Argentina. In: Litter, M.I., Nicolli, H.B., Meichtry, J.M., Quici, N., Bundschuh, J., Bhattacharya, P., Naidu, R. (eds) One Century of the Discovery of Arsenicosis in Latin America (1914-2014), CRC Press, London, pp. 644-645.

[65] Aballay, L.R., Díaz, M. del P., Francisca, F.M., Muñoz, S.E. 2012. Cancer incidence and pattern of arsenic concentration in drinking water wells in Córdoba, Argentina. Int. J. Environ. Health Res. 22:220-231.

[66] Martin, E., González-Horta, C., Rager, J., Bailey, K.A., Sánchez-Ramírez, B., Ballinas-Casarrubias, L., Ishida, M.C., Gutiérrez-Torres, D.S., Hernández Cerón. R., Viniegra Morales, D., BaezaTerrazas, F.A., Saunders, R.J., Drobná, Z., Mendez, M.A., Buse, J.B., Loomis, D., Jia, W., García-Vargas, G.G., Del Razo, L.M., Stýblo, M., Fry, R. 2015. Metabolomic characteristics of arsenic-associated diabetes in a prospective cohort in Chihuahua, Mexico. Toxicol. Sci. 144:338-346.

[67] Yuan, Y., Marshall, G., Ferreccio, C., Steinmaus, C., Selvin, S., Liaw, J., Bates, M.N., Smith, A.H. 2007. Acute myocardial infarction mortality in comparison with lung and bladder cancer mortality in arsenic-exposed region II of Chile from 1950 to 2000. Am. J. Epidemiol. 166: 1381-1391.

[68] Osorio-Yáñez, C., Ayllon-Vergara, J.C., Aguilar-Madrid, G., Arreola-Mendoza, L., Hernández-Castellanos, E., Barrera-Hernández, A., De Vizcaya-Ruiz, A., Del Razo, L.M. 2013. Carotid intima-media thickness and plasma asymmetric dimethylarginine in Mexican children exposed to inorganic arsenic. Environ. Health Perspect. 121:10906.

[69] Zaldivar, R. 1980. A morbid condition involving cardio- vascular, bronco pulmonary, digestive and neural lesions in children and young infants after dietary arsenic exposure. Zbl. Bakt. I Abt. Orig. B. 170: 44-56.

[70] Robles-Osorio, M.L., Pérez-Maldonado, I.V., del Campo, D.M., Montero-Perea, D., Avilés-Romo, I., Sabath-Silva, E., Sabath, E. 2012. Urinary arsenic levels and risk of renal injury in a cross-sectional study in open population. Rev. Invest. Clin. 64:609-614.

[11] Ministerio de Salud (MSAL). 2011. Hidroarsenicismo crónico regional endémico (HACRE). Módulo de capacitación para atención primaria. Programa Nacional para la Prevención y Control de las Intoxicaciones (PRECOTOX). Ministerio de Salud. http:/www.msal.gob.ar/images/stories/bes/graficos/0000000332cnt-03-Capacit_hidroarsenicismo. pdf. (Accessed November 2018).

[72] Ministerio de Salud (MINSAL). Guía Clínica: Vigilancia Biológica de la Población Expuesta a Arsénico, beneficiarios de la ley 20.590. Santiago: MINSAL, 2014. https://www.minsal.cl/sites/default/files/files/Guia_Clinica_Vigilancia Arsenico_final.pdf. (Accessed November 2018). 
[73] Ministerio de Salud (MINSA). 2012. Guía de practica clínica para el diagnóstico y tratamiento de la intoxicación por arsénico, 2012 Perú. http://bvs.minsa.gob.pe/local/MINSA/2109.pdf. (Accessed November 2018).

[74] López-Carrillo, L., Gamboa-Loira, B., Becerra, W., Hernández-Alcaraz, C., Hernández-Ramírez, R.U., Gandolfi, A.J., Franco-Marina, F., Cebrián, M.E. 2016. Dietary micronutrient intake and its relationship with arsenic metabolism in Mexican women. Environ. Res. 151:445-450.

[75] Kordas, K., Queirolo, E.I., Mañay, N., Peregalli, F., Hsiao, P.Y., Lu, Y., Vahter, M. 2016. Low-level arsenic exposure: Nutritional and dietary predictors in first-grade Uruguayan children. Environ Res. 147:16-23.

[76] Código Alimentario Argentino. 2012. Bebidas hídricas, aguas y aguas gasificadas. Capítulo XII. http://www.anmat. gov.ar/alimentos/codigoa/CAPITULO_XII.pdf. (Accessed January 2018).

[77] Instituto Boliviano de Normalización y Calidad A Norma Boliviana NB 512-2010, Agua potable - Requisitos.

[78] Health Brazil. 2011. Standards and drinkability standard of water intended for human consumption. Administrative Rule 2914, Brasília.

[79] NCh 409/1 Instituto nacional de Normalización, INN-Chile. 2005. Drinking Water- Part 1- Requirements.

[80] CAPRE. 1994. Normas de Calidad del Agua para Consumo Humano. Regional committee coordinator of potable water supply institutions and sanitation of Central America, Panamá, and Dominican Republic, San José.

[81] Ministerio de Salud, Costa Rica. 2005. Reglamento para la Calidad del Agua Potable. Pub. L. No. $32327-$ S.

[82] Ministerio de la Protección Social y Ministerio de Ambiente, Vivienda y Desarrollo Territorial. Resolución 2115. 2007. República de Colombia, Bogotá.

[83] INEN (Instituto Ecuatoriano de Normalización). 2006. Norma 1108: Sobre requisitos del agua potable. Registro Oficial No 231, Quito, Ecuador.

[84] Guatemala, Ministerio de Salud Pública y Asistencia Social, Unidad Ejecutora del Programa de Acueductos Rurales. 2001. Norma guatemalteca obligatoria, agua potable (especificaciones), CONGUANOR, NGO, 29.001. Guatemala: UNEPAR.

[85] Modificación a la Norma Oficial Mexicana NOM-127-SSA1-1994. 2000. Salud Ambiental. Agua para uso y consumo humano. Límites permisibles de calidad y tratamientos a los que debe someterse el agua para su potabilización. Diario Oficial de la Federación, 22 noviembre de 2000, Mexico City, Mexico.

[86] INAA. 2001. Normas Técnicas para el diseño de abastecimiento y potabilización de agua. Normas NTON 09003-99.

[87] Ministerio de Salud. Reglamento de la calidad del agua para consumo humano. Lima: Dirección General de Salud Ambiental. 2011. http://www.digesa.minsa.gob.pe/publicaciones/descargas/Reglamento_Calidad_Agua.pdf. (Accessed November 2018).

[88] UNIT 2010, Instituto Uruguayo de Normas Técnicas (UNIT-BID/Fomin) Referencia 833:2008. Agua Potable: Requisitos. http://www.ose.com.uy/descargas/Clientes/Reglamentos/unit_833_2008_.pdf (Accessed January 2014).

[89] Gaceta Oficial de la República de Venezuela Año CXXV - Mes V Caracas, 13 de febrero de 1.998, Número 36.395, Ministerio de Sanidad y Asistencia Social Número S.G.-018-98 11 De 02 De $1.998187^{\circ}$ Y 138.

[90] Litter, M.I., Morgada, M.E., Bundschuh, J. 2010. Possible treatments for arsenic removal in Latin American waters for human consumption. Environ. Pollut. 158:1105-1118.

[11] Sancha, A.M., Castro, M. L. 2001. Arsenic in Latin America: Occurrence, Exposure, Health Effects and Remediation. In: Chappell, W.R., Abernathy, C.O., Calderon, R.L. Arsenic Exposure and Health Effects IV, Elsevier B.V., Amsterdam, pp. 88-96.

[92] Höll., W., Litter, M.I. 2010. Ocurrencia y química del arsénico en aguas. Sumario de tecnologías de remoción de arsénico de aguas. In: Litter, M.I., Sancha, A.M., Ingallinella, A.M. (eds) Tecnologías económicas para el abatimiento de arsénico en aguas, Editorial Programa Iberoamericano de Ciencia y Tecnología para el Desarrollo, Buenos Aires, pp. 17-31. 
[93] Litter, M., Fernández, R., Cáceres, R., Grande Cobián, D., Cicerone, D., Fernández Cirelli, A. 2008. Tecnologías de bajo costo para el tratamiento de arsénico a pequeña y mediana escala. Revista Ingeniería Sanitaria y Ambiental 100:41-50.

[94] Cortina, J.L., Litter, M.I., Gibert, O., Valderrama, C., Sancha, A.M., Garrido, S., Ciminelli, V.S.T. 2016. Latin American experiences in arsenic removal from drinking water and mining effluents. In: Innovative Materials and Methods for Water Treatment-Separation of Cr and As, N. Kabay, M. Bryjak (eds), CRC-Taylor \& Francis, pp. $391-416$.

[95] Litter, M.I., Bundschuh, J. 2012. Emerging options for solving the arsenic problems of rural and periurban areas in Latin America. In: Ng, J.C., Noller, B.N., Naidu, R., Bundschuh, J., Bhattacharya P. (eds.) Understanding the Geological and Medical Interface of Arsenic. Taylor and Francis Group, London, pp. 267-270.

[96] Litter, M.I., Alarcón-Herrera, M.T., Arenas, M.J., Armienta, M.A., Avilés, M., Cáceres, R.E., Cipriani, H.N., Cornejo, L., Dias, L.E., FernándezCirelli, A., Farfán, E.M., Garrido, S., Lorenzo, L., Morgada, M.E., Olmos-Márquez, M.A., Pérez-Carrera, A. 2012. Small-scale and household methods to remove arsenic from water for drinking purposes in Latin America.Sci. Total Environ. 429:107-122.

[97] Hering, J.G., Chen, P.Y., Wilkie, J.A., Elimelech, M. 1997. Arsenic removal from drinking water during coagulation. J. Environ Eng ASCE 123:800-807.

[98] Bundschuh, J., García, M.E., Birkle, P., Cumbal, L.H., Bhattacharya, P., Matschullat. J. 2009. Occurrence, health effects and remediation of arsenic in groundwaters of Latin America. In: Bundschuh, J., Armienta, M.A., Birkle, P., Bhattacharya, P., Matschullat, J., Mukherjee, A.B. (eds) Natural arsenic in groundwater of Latin America. CRC Press/ Balkema Publisher, Leiden, pp. 3-15.

[99] Sancha, A.M. 2010. Remoción de arsénico por coagulación y precipitación. In: Litter, M.I., Sancha, A.M., Ingallinella, A.M. (eds) Tecnologías económicas para el abatimiento de arsénico en aguas, Editorial Programa Iberoamericano de Ciencia y Tecnología para el Desarrollo, Buenos Aires, pp. 33-41.

[100] Sancha, A.M. 2010. Importancia de la matriz de agua a tratar en la selección de las tecnologías de abatimiento de arsénico. In: Litter, M.I., Sancha, A.M., Ingallinella, A.M. (eds) Tecnologías económicas para el abatimiento de arsénico en aguas, Editorial Programa Iberoamericano de Ciencia y Tecnología para el Desarrollo, Buenos Aires, pp. $145-153$.

[101] Sancha, A.M. 2010. Experiencia chilena en la remoción de arsénico a escala de planta de Tratamiento. In: Litter, M.I., Sancha, A.M., Ingallinella, A.M. (eds) Tecnologías económicas para el abatimiento de arsénico en aguas, Editorial Programa Iberoamericano de Ciencia y Tecnología para el Desarrollo, Buenos Aires, pp. 169-178.

${ }^{[102]}$ Bundschuh, J., Litter, M., Ciminelli, V., Morgada, M.E., Cornejo, L., Garrido Hoyos, S., Hoinkis, J., Alarcón-Herrera, M.T., Armienta, M.A., Bhattacharya, P. 2010. Emerging mitigation needs and sustainable options for solving the arsenic problems of rural and isolated urban areas in Iberoamerica - A critical analysis. Water Res. 44:5828-5845.

[103] Ingallinella, A.M., Fernández, R.G. 2010. Experiencia argentina en la remoción de arsénico por diversas tecnologías. In: Litter, M.I., Sancha, A.M., Ingallinella, A.M. (eds), Tecnologías económicas para el abatimiento de arsénico en aguas, Editorial Programa Iberoamericano de Ciencia y Tecnología para el Desarrollo, Buenos Aires, pp. $155-167$.

${ }^{[104]}$ Hering, J.G., Katsoyiannis, I.A., Ahumada Theoduloz, G., Berg, M., Hug, S.J. 2017. Arsenic Removal from Drinking Water: Experiences with Technologies and Constraints in Practice. J. Environ. Eng. 143:1-1.

${ }^{[105]}$ Cardoso, S., Grajeda, C., Argueta, S., Garrido, S. 2010. Experiencia satisfactoria para la remoción de arsénico en Mixco, Guatemala. In: Litter, M.I., Sancha, A.M., Ingallinella, A.M. (eds), Tecnologías económicas para el abatimiento de arsénico en aguas, Editorial Programa Iberoamericano de Ciencia y Tecnología para el Desarrollo, Buenos Aires, pp. 179-189.

[106] Alarcón-Herrera, M.T., Martín-Domínguez, I.R., Benavides Montoya, A. 2007. Wetlands for arsenic removal. In: WETPOL 2007 2nd International Symposium on Wetland Pollutant Dynamics and Control, Tartu, Estonia.

${ }^{[107]}$ Litter, M.I., Pereyra, S., LópezPasquali, C.E., Iriel, A., Senn, A.M., García, F.E., Blanco Esmoris, M.F., Rondano, K., Pabón, D.C., Dicelio, L.E., Lagorio, M.G., Noel, G.D. 2015. Remoción de arsénico en localidades de la provincia de Santiago del Estero, Argentina. Evaluación del acceso, uso y calidad de agua en poblaciones rurales con problemas de arsénico, Rev. Ing. Sanit. Amb. 125:13-25. 


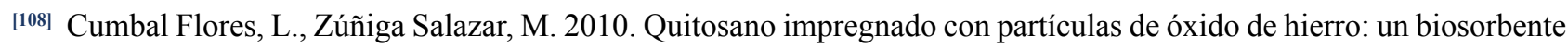
que remueve selectivamente arsénico de aguas. In: Litter, M.I., Sancha, A.M., Ingallinella, A.M. (eds). Tecnologías económicas para el abatimiento de arsénico en aguas, Editorial Programa Iberoamericano de Ciencia y Tecnología para el Desarrollo, Buenos Aires, pp. 269-289.

[109] Castro de Esparza, M.L. 2010. Remoción de arsénico del agua de pozos de zonas rurales de Puno, Perú empleando ALUFLOC. In: Litter, M.I., Sancha, A.M., Ingallinella, A.M. (eds), Tecnologías económicas para el abatimiento de arsénico en aguas, Editorial Programa Iberoamericano de Ciencia y Tecnología para el Desarrollo, Buenos Aires, pp. 243-255.

[110] Morgada, M.E., Litter, M.I. 2010. Tecnologías fotoquímicas y solares para la remoción de arsénico de soluciones acuosas. Estado del arte. In: Litter, M.I., Sancha, A.M., Ingallinella A.M. (eds) Tecnologías económicas para el abatimiento de arsénico en aguas, Editorial Programa Iberoamericano de Ciencia y Tecnología para el Desarrollo, Buenos Aires, pp. 73-89.

[111] Morgada, M.E., Levy, I.K., Salomone, V., Farías, S.S., López, G., Litter, M.I. 2009. Arsenic(V) removal with nanoparticulate zerovalent iron: effect of UV light and humic acids. Catal. Today 143:261-268.

${ }^{[112]}$ Kunz, S., Romero, L.G., Otter, P., Feller, J. 2017. Treatment of arsenic-contaminated water using in-line electrolysis, co-precipitation and filtration in Costa Rica, Water Sci. Technol. Water Supply 18(1):ws2017089 DOI: 10.2166/ ws.2017.089.

[113] Pérez Coll, C.S., Pabón-Reyes, C., Meichtry, J.M., Litter, M.I. 2018.Monitoring of toxicity of As(V) solutions by AMPHITOX test without and with treatment with zerovalent iron nanoparticles. Environ. Toxicol. Pharmacol. $60: 138-145$.

\section{Bios}

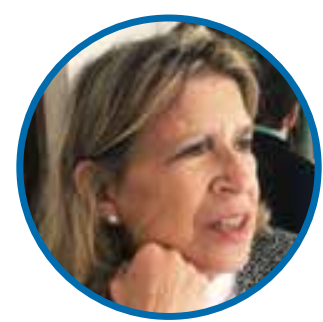

\section{Marta I. Litter}

Prof. Dr. Marta Litter has a $\mathrm{PhD}$ in Chemistry (Buenos Aires University, Argentina), with postdoctoral studies at the University of Arizona, USA. She is Senior Researcher of the National Research Council (CONICET), Full Professor at the National University of General San Martín (UNSAM) and has been Head of the Division of Environmental Chemistry Remediation (National Atomic Energy Commission), all of this in Argentina. She has more than 200 scientific publications in international journals, books and book chapters. She was the International Coordinator of the Iberoarsen CYTED network. She received the Mercosur Prize in Science and Technology (2006 and 2011) and was President of the International Congress on Arsenic in the Environment (2014). She is an active member of the 'Arsenic in water' ad-hoc group of experts of the Food Safety Network of the National Scientific and Technical Research Council (Red de Seguridad Alimentaria, CONICET). She is considered a pioneer in photocatalysis in Argentina (2016) and has been accepted as a Member of TWAS (2018). Corresponding author. Email: marta.litter@ gmail.com.

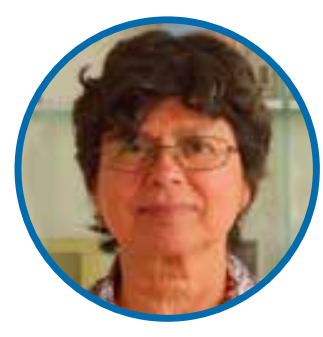

\section{María Aurora Armienta Hernández}

Dr. María Aurora Armienta Hernández is a Research Professor at Geophysics Institute, Autonomous National University of Mexico (UNAM), Mexico.

She has a Bachelor in Chemical Engineering, a M.Sc. in Analytical Chemistry, and a $\mathrm{PhD}$ in Hydrology. Her research is focused on environmental geochemistry, hydrogeochemistry, medical geology and geochemical processes related to volcanic activity. She has identified contamination processes and sources of metals and metalloids in groundwater, rivers and soils in various regions in Mexico, and developed solutions to the pollution problem. She has published 118 international peer reviewed articles, 47 extended abstracts, and 30 book chapters. Dr. Armienta has supervised $12 \mathrm{PhD}, 19$ M.Sc., and 30 Bachelor theses. She has been awarded a Level III National Researcher (the highest level) by the National Science Council of Mexico. She was the Mexican coordinator of the Iberoarsen international network. In March 2013, she received the "Juana Ramírez de Asbaje" award in recognition of her academic achievements at the University of Mexico. In 2012, 2013 and 2014 she was one 
of the ten most cited UNAM researchers in Earth sciences. In 2015, Dr. Armienta received the Academic and Research career recognition by the Mexican Geohydrological Society, and in 2018 she was named Teacher of the Year in Earth Sciences by the Mexican Geophysical Union.

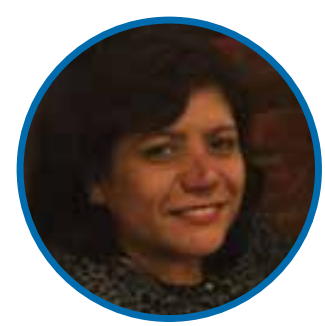

\section{Ruth Esther Villlanueva- Estrada}

Dr. Ruth Esther Villanueva-Estrada graduated as Chemist at the School of Chemistry, at the Autonomous National University of México (UNAM) (1996), where she later on obtained a Master's degree in Chemical Oceanography (2001) and a Doctorate in Geochemistry (2007). She is a staff member of the Geophysics Institute, Group of Dangers and Risks by Natural Phenomena (UNAM). She has published 23 articles in high-impact indexed journals, 3 book chapters, 10 extensive abstracts with arbitration and 7 technical reports. Currently, she is Head of Laboratory at the Geothermal Fluids Geochemistry, Geophysics Institute (UNAM-Michoacán Unit). Her research focuses on studies on A) renewable energy resources geochemistry, B) aqueous environmental geochemistry, and $\mathrm{C}$ ) geochemical modeling of water-rock interaction.

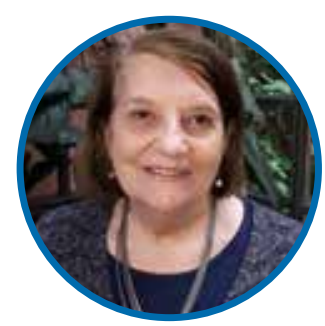

\section{Edda C. Villaamil Lepori}

Prof. Dr. Villaamil Lepori has obtained a doctorate at the University of Buenos Aires, Toxicology Area (2000). She is Consulting Professor at the University of Buenos Aires, and Honorary Active Partner and Member of the Scientific Advisory Board of the International Life Sciences Institute (ILSI) in Argentina. She is the author of 71 articles published in specialized journals, 6 book chapters, and 314 papers presented at scientific meetings. On 77 occasions, she was a speaker at national and international meetings, and she has received 18 awards and distinctions. She is an experienced human resources trainer - she has directed research groups, doctoral and postdoctoral students, residents, researchers from CONICET and UBA, and interns from national and foreign universities. Considering national subsidized research projects (FONCyT, FONTAR, CONICET, UBACyT, SECyT-MINCyT) she has directed 13 projects, co-directed 7 projects, participated as a researcher in 17 projects, and has coordinated 3 international projects in the region (AECI) related to the topic of Arsenic. She acts in the area of Toxicology, with emphasis on Toxicology of Persistent Pollutants, Environmental Toxicology and Occupational Toxicology. In her professional activities she has interacted with 129 collaborators in co-authorships of scientific works.

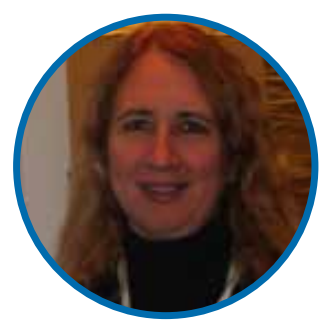

\section{Valentina Olmos}

Dr. Valentina Olmos has obtained a Doctorate in Pharmacy and Biochemistry at the University of Buenos Aires (2016). She is Researcher and Professor Teaching Assistant at the School of Pharmacy and Biochemistry, University of Buenos Aires. Her research is focused on arsenic exposure assessment and arsenic health risk assessment. She is an Emeritus member of the Argentine Society of Toxicology (Asociación Toxicológica Argentina) and a full member of the Society of Toxicology (SOT, USA). She is review editor at Acta Toxicológica Argentina Journal since 2006. She is an active member of the 'Arsenic in water' ad-hoc group of experts of the Food Safety Network of the National Scientific and Technical Research Council (Red de Seguridad Alimentaria, CONICET). She authored 33 scientific publications in national and international scientific journals. She authored more than 50 presentations to national and international scientific meetings. 